Productivity growth in Indian banking: Who did the gains accrue to?

Rajeswari Sengupta and Harsh Vardhan

Indira Gandhi Institute of Development Research, Mumbai June 2020 


\title{
Productivity growth in Indian banking: Who did the gains accrue to?
}

\author{
Rajeswari Sengupta and Harsh Vardhan
}

Email(corresponding author): rajeswari@igidr.ac.in

\begin{abstract}
In this paper we analyse the beneficiaries of productivity gains in the Indian banking sector during the period from 1992 to 2019. We document the relative efficiency of different groups of banks by ownership. We find that the Indian banking sector, particularly the public sector banks experienced steady productivity growth from the mid 1990s till about 2010. We conduct a detailed descriptive analysis to examine the various stakeholders that the productivity gains have accrued to, over the years and across bank groups. We conclude that most of the gains may have accrued to the shareholders which for the public sector banks would mean the government. These gains presum-ably helped reduce the burden on the government of capitalising the public sector banks, especially during the 1997-2002 period of sharp rise in non performing assets.
\end{abstract}

Keywords: Banking sector, Bank productivity, Beneficiaries, Efficiency gains.

JEL Code: G21, G28, D24, D61 


\title{
Productivity growth in Indian banking: Who did the gains accrue to?
}

\author{
Rajeswari Sengupta* Harsh Vardhan ${ }^{\dagger}$
}

This version: June 2020

\begin{abstract}
In this paper we analyse the beneficiaries of productivity gains in the Indian banking sector during the period from 1992 to 2019. We document the relative efficiency of different groups of banks by ownership. We find that the Indian banking sector, particularly the public sector banks experienced steady productivity growth from the mid 1990s till about 2010. We conduct a detailed descriptive analysis to examine the various stakeholders that the productivity gains have accrued to, over the years and across bank groups. We conclude that most of the gains may have accrued to the shareholders which for the public sector banks would mean the government. These gains presumably helped reduce the burden on the government of capitalising the public sector banks, especially during the 1997-2002 period of sharp rise in non performing assets.
\end{abstract}

JEL classification: G21, G28, D24, D61

Keywords: Banking sector, Bank productivity, Beneficiaries, Efficiency gains.

\footnotetext{
*Assistant Professor of Economics at Indira Gandhi Institute of Development Research (IGIDR), Mumbai. Email: rajeswari@igidr.ac.in.

${ }^{\dagger}$ Executive-In-Residence at the Centre of Financial Services, SP Jain Institute of Management \& Research. Email ID: harshv89@yahoo.com.
} 


\section{Introduction}

An important source of economic growth is productivity growth. Productivity can be studied at the level of the entire economy and also for specific sectors. The banking sector is a significant pillar of the Indian economy and is the cornerstone of financial intermediation. Since the deregulation and privatisation reforms of the early 1990s, Indian banking has witnessed many significant changes such as the rapid growth of privately owned banks, gradual penetration of computers and information technology in all strata of banking, improved risk management practices, and so on. All these changes would have important implications for the overall productivity of the banking sector.

One parameter that demonstrates these gains is employment in banking. Between 1991 and 2010, despite growing at over 15\%, Indian banking did not add to net employment. It employed about the same number of people in 2010 as it did in 1991 (see figure 1). In fact, employment fell across both private and public sector banks between 2000 and 2009. Yet during this period, the banking sector balance sheet grew by $25 \%$. Balance sheet per employee grew phenomenally between mid 1990s and 2010 (see figure 2). This hints at dramatic improvements in productivity 1

Another indicator of productivity growth is consistent reduction in costs. Operating costs as percentage of total assets began declining from mid 1990s onwards, implying substantial productivity gains. Since roughly 2010 however, it appears that productivity growth in the overall banking sector has slowed down and may have even stalled. The data also reveals some convergence that has taken place between private and public sector banks (PSBs) in terms of productivity gains.

In this paper, we throw some light on who have been the main beneficiaries of these efficiency gains witnessed by the Indian banking sector in the mid 1990s to 2010 period. To the best of our knowledge, this is the first attempt to investigate who have the productivity gains accrued to among the various stakeholders in the banking sector.

There exist a number of studies that analyse efficiency in the Indian banking sector in the post-1991 reform period. Majority of these studies have explored the effect of the deregulation and liberalisation reforms of

\footnotetext{
${ }^{1}$ There are multiple categories of banks in India such as commercial banks, co-operative banks, regional rural banks etc. In this paper we primarily focus on the scheduled commercial banks who account for more than $95 \%$ of the credit and deposits in the entire banking system.
} 
early 1990s on productivity growth in the banking sector ${ }^{2}$ However none of these studies has explored the potential beneficiaries of the productivity gains. As the literature survey of Berger and Humphrey (1997) shows, studies on bank efficiency can contribute to policy making, academic research and can be useful for improving bank management.

The four main stakeholders who can benefit from productivity gains in banking are employees, depositors, borrowers, and shareholders. It is likely that parts of the gains accrued to all these classes of claimants. We try to assess how much each of these stakeholders benefitted from the gains. It is also likely that the beneficiaries and/or the extent of gains that accrued to them varied across types of banks. We attempt to examine this variation as well.

Studying productivity gains in banking is important as it is a critical sector of the Indian economy and its performance determines to a considerable extent the performance of the whole economy. Banking has been the largest service sector employer and accounts for one of the largest shares of organised employment. Banking is also a highly regulated sector and hence the government through regulatory policies can significantly impact the behaviour and performance of banks. Understanding not only what drives productivity but also who benefits from it could be an important guide to regulatory policy.

Unlike most other businesses, banking has customers on both sides of the balance sheet. Depositors as well as borrowers are customers of banks and hence have legitimate claims on any productivity gain. Owners (i.e. shareholders including the government, considering that $70 \%$ of Indian banking is owned by the government) and employees are the critical 'internal' stakeholders who also have legitimate claims on productivity gains made by banks. With sizeable productivity gains over two decades, it will be instructive to understand how the gains were shared between these four main stakeholders. It would provide insights into the relative bargaining power of the stakeholders.

Based on preliminary data analysis we find that the biggest beneficiary of the productivity gains of the Indian banking sector have been the shareholders which in the case of the PSBs implies the government. The other stakeholders i.e. depositors, borrowers and employees do not seem to have benefitted substantially from the efficiency gains. We argue that the gains

\footnotetext{
${ }^{2}$ See for example, Bhattacharyya et al. (1997), Bhattacharyya and Pal (2013), Sathye (2003), Das et al. (2005), Das and Ghosh (2006), Kumar and Gulati (2009), Das and Shanmugam (2004), Sensarma (2006), Casu et al. (2010), Sanyal and Shankar (2011) among others.
} 
that have accrued to the government as the primary owner of the PSBs may have in turn been used to bail out the defaulting borrowers during times of rising non performing assets on the banks' balance sheets. We also conjecture that one reason for such skewed distribution of productivity gains could be the lack of competition in the banking sector. $70 \%$ of the commercial banks in India are owned by the government and they essentially act like one bank with different names thereby rendering the sector non-competitive. Therefore, one way to distribute the efficiency gains more equitably among all the stakeholders could be to reduce the market share of the government owned banks.

In the rest of the paper we briefly discuss the patterns of productivity growth in Indian banking in section 2, We conduct a detailed analysis of the beneficiaries of productivity gains in section 3. Finally we conclude in section 4 .

\section{Productivity gains in Indian banking}

In 1991, India embarked upon a policy of economic liberalisation with the objective to gradually transition into a capitalist, free market economy. A strong and stable banking system was critical to ensure economic growth. The policy changes made between 1993 and 1995, ushered in a dramatic shift in banking in India. New banking licenses were issued to private sector companies. These new private sector banks started operations in the mid 1990s.

The new private sector banks introduced an element of competition in the Indian banking landscape. They started with superior technology platforms that helped them scale rapidly and efficiently. Public sector banks (PSBs) responded by adopting technology through efforts on implementing core banking solution, branch networking etc. They also downsized their overstaffed organisations by offering 'voluntary retirement schemes' (VRSs) to reduce headcount. The government also started the process of listing the shares of the banks it owned. Listing of shares brought the PSBs under scrutiny of the equity market participants who demanded greater focus on commercial objectives, including productivity.

These structural changes in Indian banking in the early and mid 1990s got reflected in significant gains in productivity. An important metric for measuring productivity of the banking system is the cost of intermediation. Banks, as financial intermediaries between savers and borrowers, incur costs in transforming savings into credit. The cost of intermediation mainly consists of costs of operations of the banking system i.e. costs of manpower and 
establishment and other items such as information technology (IT) related costs. The cost of intermediation must come down for the system to enjoy productivity gains.

In this paper we measure the cost of intermediation as the ratio of total operating costs to average total assets (or liabilities). We also present other related measures such as the ratio of total operating costs to average total income (sum of net interest income and other income). Figure 3 shows both the measures ${ }^{3}$ The figure shows a secular decline in the cost of intermediation from mid 1990s until about 2010 after which it remains mostly constant and goes up slightly in 2018 and 2019.

Measured as a percentage of average total assets the cost of intermediation came down from around $3 \%$ to around $1.9 \%$ for the banking system as a whole i.e. a gain of 110 basis points. As a percentage of the total income, the cost of intermediation came down from around 60\% in 1992 to roughly $45 \%$ by 2010 and remained at that level until 2018 before going up in 2019 . On this metric, there is a gain of around $15 \%$ over this period. This suggests that the Indian banking system witnessed productivity gains from 1992 until roughly 2010 after which productivity appears to have stagnated.

As mentioned earlier, with the advent of the new private sector banks in mid 1990s, the PSBs faced acute competition 4 They responded by aggressively adopting technology. In figure 4 we show the evolution of the cost of intermediation for four groups of banks over the period from 1992 to 2019. The four groups are, the State Bank of India (SBI) group, PSBs other than SBI, private banks including both old and new private banks, and foreign banks, which are branches of international banks operating in India. ${ }^{5}$

Figure 4 reveals an interesting pattern in productivity gains. Government owned banks including the SBI group, the old private sector banks and foreign banks, all had similar levels of intermediation costs in early 1990s, at around $3 \%$ of total assets. The new private sector banks started in the mid 1990s with structurally lower cost levels, largely due to their superior technology platforms. As these banks expanded rapidly into sizeable businesses from the mid 1990s onwards, they benefitted from the economies of

\footnotetext{
${ }^{3}$ All data used in our analysis have been obtained from the Reserve Bank of India.

${ }^{4}$ Private banks, prior to 1995 , comprised the so called 'old private sector banks' that were considered too small to be nationalised and hence continued with private ownership but had organisations and operations very similar to the government owned banks.

${ }^{5}$ The SBI group has several separate banks which were all subsidiaries of SBI until they merged into SBI in 2018. We kept SBI and its subsidiaries as a separate group given that it is the biggest and the most widely present bank (in terms of branches) and hence it might have some pricing advantage.
} 
scale and their operating costs came down sharply.

The scale effects plateaued by mid 2000s as they reached a certain size. Also the operating costs seem to have gone up from early 2000s onwards presumably due to higher wages and salaries offered to their employees. As shown in figure 11, private banks see a sharp increase in real per employee cost between 2002 to 2008 that potentially muted their productivity gains. These costs decline in the period thereafter but by the mid 2000s the productivity gains ran their course. Overall operating cost levels remained more or less flat for these banks since then, especially since 2010 .

Government owned banks, both the SBI group and the non-SBI PSBs, witnessed steep gains in productivity, beginning mid 1990s as reflected in the sharp drop in the cost of intermediation. By the mid 2000s, the government owned banks, especially the non-SBI PSBs, had lower cost of intermediation than the private or foreign banks presumably as a result of their "catchingup" through adoption of superior technology as well as some scale effect given that they were much bigger in size compared to the private banks.

All four groups appear to have hit a stagnation in productivity gains by 2010. Their cost of intermediation has stayed more or less constant since then. There is also some convergence in the cost of intermediation across the four groups with PSBs' averaging around $1.65 \%$ in recent years, private banks at around $2.25 \%$ with foreign banks and the SBI group in between.

\section{$3 \quad$ Beneficiaries of productivity gains}

The above discussion implies that in the post-reform period, the Indian banking sector experienced significant productivity gains till about 2010 . Stagnant productivity since 2010 suggests that the gains made have been permanently embedded in the banking system i.e. they have not been diluted subsequently. It is therefore important to understand who among the four categories of stakeholders (namely, owners, depositors, borrowers and employees) benefitted from these producitivity gains. In this section we analyse each of these four stakeholders and attempt to assess their share of the productivity gains. In the absence of a plausible empirical framework to assess this issue, we resort to descriptive analysis of the data, and reserve a more rigorous investigation for the future. 


\subsection{Depositors}

Indian commercial banks offer three types of deposits - (i) demand deposits (commonly known as current account deposits and are similar to checking accounts in the US), (ii) savings account deposits and (iii) term deposits (also known as fixed deposits). Of these, demand deposits do not carry any interest. Until 2012, interest rate on savings account deposits (accounting for roughly $25-30 \%$ of a bank's deposit base) was regulated by the government at 4\%. Even after deregulation most banks adhered to the old levels of $4 \% .6$ Only the term deposits are priced based on market conditions and their pricing reflects prevailing interest rates and competitive dynamics in the deposit business.

This implies that if the depositors benefitted from productivity gains, we would expect the term deposit pricing to improve over time relative to a suitable reference rate. Accordingly, in figure 5 we plot the annual average interest rate on term deposits and the 5 year government security yield from 1997 to 2019.7 Average maturity of term deposits in Indian banks is around 2.6 years (ranges between 2.5 to 2.8 years), and hence 5 year government security is the closest reference yield with reliable data 8 The reason for using data from 1997 is that reliable data on government security yields prior to 1997 is not available. The objective is to compare the pricing of deposits with a reliable reference rate which is independent of the competitive dynamics of the banking sector.

We find that during the period of study, especially during the mid 1990s to 2010 when the banking sector experienced producitivity growth, there was no appreciable improvement in the term deposit pricing relative to the risk-free reference rate i.e. the G-Sec yield. This suggests that depositors may not have received any part of the productivity gains. Average term deposit has been priced during this period at a discount of around 50 to 70 basis points and the discount has stayed in the same range. This implies

\footnotetext{
${ }^{6}$ With the exception of two small private banks whose deposit market share was less than $2 \%$. Presumably banks continued with the low deposit rates because no bank had the incentive to compete on price. The gain in market share was potentially seen to be minimal and losses quite high as the entire stock of savings accounts would have to be repriced.

${ }^{7}$ Interest on term deposits is calculated as the difference between total interest on deposits and interest on savings account (calculated at about $3.8 \%$ on average deposits). Interest rate of term deposits is obtained as the ratio of interest on term deposits and average term deposits across two consecutive years. While the rate on saving account is $4 \%$ effectively the rate works out to about $3.8 \%$ as banks take the average balance between the 5 th and the 25 th of each month. The analysis does not change if we take the rate to be $4 \%$.

${ }^{8}$ The pattern of relative pricing and hence the conclusions do not change if we use the 10 year yield or the 1 year yield.
} 
that depositors would be better off investing their savings in government securities as opposed to putting their money in term deposits with banks 9 The only exception was the period between 2001 to 2004 when the deposits were priced at premium to the reference yield 10

If we look at the same data across the various groups of banks, we see no perceptible differences in deposit pricing except for foreign banks which appear to be pricing deposits at even higher discount to the reference rate. Figure 6 presents the relative deposit pricing for the four bank groups.

\subsection{Borrowers}

Bank borrowers are important stakeholders in the banking business and rightful claimants to productivity gains. As in the case of the depositors, any sharing ofproductivity gains by the borrowers should get reflected in the pricing of loans. Loan prices should decline relative to an appropriate reference rate. In figure 7 we plot the average yield on loans for all banks and the 10 year government security yield for the period from 1997 to 201911

The figure shows that the loan prices have not declined relative to the G-Sec rate and infact the loan pricing premium over the risk-free reference rate has been more or less constant from 2005 onwards. This suggests that as in the case of depositors, the borrowers too may not have received any share of the productivity gains enjoyed by the banking system.

Loan prices typically include a risk premium and a maturity premium. Any change in the average riskiness of borrowers or in the average maturity of the loans would impact the loan premium. This implies that if during the period under review, the average maturity of loans went up or the riskiness of the average borrower increased, then even constant loan price premium might represent gains to borrowers. However, the data shows that there has been no perceptible change in average loan maturity, which has stayed constant at around 3 years. Riskiness of the average loan is hard to assess purely from publicly available data. There is however a case to be made, looking at the rapid build up of non performing loans (NPLs) in the period from 2014 to 2018 that riskiness of loans was increasing in the period from 2005 onwards which was not accompanied by a perceptible increase in loan

\footnotetext{
${ }^{9}$ We would normally expect the bank deposits to be priced slightly higher than the G-Sec yield of similar maturity to account for the credit risk in the bank.

${ }^{10}$ This could be attributed to the intense competition and hence higher pricing of term deposits due to the merger of a large Development Finance Institution (DFI) into a commercial bank. This merger compelled the bank to raise large amount of deposits to meet its reserve requirements (merger of erstwhile ICICI Ltd into ICICI Bank).

${ }^{11}$ The pattern does not change if we use the 5 year G-Sec yield instead.
} 
price premium. In the previous years (from 1997 until 2005) the loan pricing premium appears to have increased.

\subsection{Employees}

The next stakeholders that we consider are employees. Employee costs (wages and salaries) are a component of the overall cost of intermediation. Hence productivity growth measured as a reduction in the cost of intermediation would imply that employee costs would come down but the important question is, by how much on a relative scale. In figure 9 we plot the employee costs for the banking system as a percentage of average total assets, and total income.

We find that there has been a secular decline in employee costs from about $2 \%$ of average total assets to around $1 \%$. As a percentage of total income, they have come down from around $40 \%$ to roughly $30 \%$. It is worth noting that the share of employee costs in the total operating costs (not shown here) also came down from around $70 \%$ to $50 \%$.

Employee costs have come down largely because the number of employees declined between 1991 and 2010. To evaluate the possible share of employees in productivity gains of the banking system, we plot the real per employee wage cost relative to the growth in real balance sheet of the entire banking sector from 1992 to 2019 in figure 10. 12 Our hypothesis is that if the employees had shared some productivity gains, the total wage bill would come down but the per employee real (or nominal) wages would improve by at least as much as the growth in banking income or assets, if not by more.

The figure shows that during 1992-2019, the growth in real per employee wages has lagged behind the growth in banking sector balance sheet. While the real balance sheet continues to grow, real employee wage remains flat. The compounded annual growth rate (CAGR) of real per employee compensation during this period was $3.6 \%$ whereas the growth in real balance sheet of the banking system was $7.7 \%$. The CAGR in real wages was faster from 1992 to 2007 at $5.9 \%$ when the real balance sheet grew at 9.4\%. From 2007 to 2019 the real per employee wages have been almost stagnant, growing at only $0.7 \%$ annually when the real balance sheet grew at $4.9 \%$.

Figures 11 and 12 show that while for the private sector banks employee cost went up sharply in the 2002-2008 period and declined thereafter, for the public sector banks employee compensation grew more slowly until about

\footnotetext{
${ }^{12}$ The real parameters are computed by deflating the nominal numbers by the consumer price index.
} 
2010 after which it become stagnant.

This suggests that employees may not have benefitted from the productivity gains given that wage growth has been consistently lower than the growth in banking business and has been almost stagnant for the past 12 years or so.

\subsection{Shareholders}

The last stakeholders we consider are shareholders of the banks. For the PSBs, the majority owner is the government which, by law, has to maintain at least $51 \%$ ownership in these banks. For private banks, the ownerships tends to be widely distributed as the current regulations limit any individual or entity to a $5 \%$ ownership (which can go upto $10 \%$ with special approval of the regulator). Most foreign banks operate in India as branches of the parent international banks.

Figure 13 depicts the pre-provisioning operating profits (PPOP) of the banking system and the cost of intermediation. PPOP, also referred to as operating profit is the profit before risk related provisioning and hence measures the gains to the shareholders before paying for risk. As discussed earlier and shown in this figure as well, the operating cost of the banking system has been declining during the first part of the period under review. The productivity gains added to PPOP until about 2007 and then operating profits stagnated as there were negligible gains in productivity from then on. The evolution of these two parameters therefore suggests that the cost of intermediation saved by the banks went directly into the operating profits implying that it accrued to the shareholders. As discussed above, it seems that other stakeholders in banks- depositors, borrowers, and employees did not receive much of the productivity gains.

Among other uses, increases in PPOP are potentially utilised to make provision for the credit losses (losses on NPLs) that banks incur. After providing for these losses, paying taxes, and paying dividend to shareholders (if any), the residual profits add to the capital base of the bank. In order to understand the pattern of use of the gains in PPOP towards credit loss provisioning, ideally we would like to look at the data on credit loss provisioning over the same time period. Unfortunately this data in not available on a consistent basis. Hence, we look the level of non performing assets (NPAs) of the banks which would be a crucial determinant of the credit loss provisioning needed. For this we analyse three separate groups of banks: government owned banks (PSBs and SBI group together), private banks and foreign banks. 
Figure 14 shows the three variables- cost of intermediation, PPOP and gross NPAs of government owned banks as a group over the period of 1997 to 2018. The figure can be interpreted as follows. PSBs enjoyed a steady growth in productivity from mid 1990s onwards till about 2010 as reflected in the decline in their operating costs. PPOP as a proportion of average total assets increased with the productivity gains in these banks. During 1997-2005, part of the increased PPOP was presumably used to bring down the high level of gross NPAs thathad built up in the PSBs in the mid 1990s. This would imply that the productivity gains enjoyed by these banks during this period effectively went to the defaulting borrowers via PPOP and NPA provisioning. Consequently the government as the owner of the PSBs had to put in less additional capital into these banks.

With the stagnation in productivity from 2010 onwards, the growth in PPOP also got stalled. When the next round of NPA buildup started from 2011 onwards, there were not enough productivity gains to address the rise in gross NPAs. As a result, these banks had to raise large amounts of external capital from the government as the internally generated capital was not enough to provide for the NPAs.

In figure 15 we look at the same parameters for private banks. Productivity gains for the private banks as reflected through lower cost of intermediation were mostly during the period 1997-2005 and even then, were not as substantial as those for PSBs. The productivity gains enjoyed by the private sector banks were lower than the PSBs during the 2002-2010 period and stagnated from 2010 onwards. Compared to their public sector peers, the private banks also had lower levels of NPAs (Sengupta and Vardhan (2017)). Hence they would have incurred lower credit loss provisions and the issue of productivity gains going to defaulting borrowers is less relevant for them.

The patterns of productivity gain, PPOP, and NPAs appear to be different for the foreign banks. They did not gain much in terms of productivity in the mid 1990s-2008 period, compared to the PSBs and private banks. They saw substantial productivity gains in the subsequent years during which their PPOP also went up. They also had much smaller NPA levels.

\section{Conclusion}

Our descriptive analysis from 1992 to 2019 reveals that banking sector in India experienced substantial productivity gains till about 2010 after which the gains seem to have plateaued and even declined marginally in recent years. 
Among the bank groups, private sector banks which primarily began operating from 1994-95 onwards in the post-liberalisation era, witnessed sharp reductions in their operating costs even as their balance sheets expanded rapidly, indicating steady productivity improvement. These banks started on superior technology platforms which may have contributed to the steep efficiency gains. However the benefits ran their course by about mid 2000s. On the other hand, public sector banks witnessed significant productivity gains from mid to late 1990s onwards till about 2010, and their gains even surpassed that of the private banks.

When we analyse the different stakeholders of the banking system to understand who benefitted from the productivity growth, we do not find any appreciable amount of the gains accruing to the depositors, borrowers or employees. Instead it appears that much of the efficiency gains enjoyed by the banking system went to the shareholders which in the case of public sector banks would imply the government. It is also possible that the gains that accrued to the shareholders were used to deal with the losses incurred by the public sector banks on their loan books particularly during the period from 1997 to 2003 when these banks recorded high levels of non performing assets.

It might be a matter of concern for policymakers that the other stakeholders of the banking system have not been benefitting from the efficiency gains. The uneven distribution of the gains might be due to the lack of competition in the Indian banking sector. In a truly competitive banking system, all four stakeholders would have nearly equal bargaining power and this would have resulted in a more equitable distribution of the productivity gains.

The gains accruing to the borrowers would have lowered the cost of debt capital, for depositors it would have meant a better return on their savings and employees would have benefitted from higher wages. One may argue that the multiplier effect of the gains going to the (good) borrowers, depositors, and employees wouldbe much greater. This does not seem to have happened in India.

There are close to 100 scheduled commercial banks in India by now but $70 \%$ of the sector is owned by the government. In the $1990 \mathrm{~s}$, public sector banks accounted for $90 \%$ of the total size of the banking sector. These banks look nearly identical to each other in all aspects of banking business. Thus, despite there beinga large number of banks in India there is hardly any element of competition among them. Government ownership has resulted in a near monopolistic, non-competitive banking sector where any gains from efficiency improvement instead of getting passed on to the broader economy, accrue to the owners i.e. the government and are in turn used to effectively 
bail-out the defaulting borrowers.

To ensure a more equal and broad based distribution of the productivity gains of the banking sector among all the relevant stakeholders, perhaps what is needed is a gradual reduction in the market share of the government owned banks so that there is greater heterogeneity among the banks and hence greater competition in the banking sector. 


\section{References}

Berger, Allen N. and David B. Humphrey, "Efficiency of financial institutions: international survey and directions for future research," European Journal of Operational Research, April 1997, 98.

Bhattacharyya, Aditi and Sudeshna Pal, "Financial Reforms and Technical Efficiency in Indian Commercial Banking: A Generalized Stochastic Frontier Analysis," Review of Financial Economics, November 2013, 22 (3), 109-117.

Bhattacharyya, Arunava, C. Lovell, and Pankaj Sahay, "The impact of liberalization on the productive efficiency of Indian commercial banks," European Journal of Operational Research, 1997, 98 (2), 332-345.

Casu, Barbara, Alessandra Ferrari, and Tianshu Zhao, "The impact of regulatory reforms on cost structure, ownership and competition in Indian banking," Journal of Banking \& Finance, January 2010, 34 (1), 246-254.

Das, Abhiman and K. R. Shanmugam, "Efficiency of Indian commercial banks during the reform period," Applied Financial Economics, 2004, $14(9), 681-686$.

- and Saibal Ghosh, "Financial deregulation and efficiency: An empirical analysis of Indian banks during the post reform period," Review of Financial Economics, 2006, 15 (3), 193-221.

_ , Ashok Nag, and Subhash C. Ray, "Liberalisation, Ownership and Efficiency in Indian Banking: A Nonparametric Analysis," Economic and Political Weekly, 2005, 40 (12), 1190-1197.

Kumar, Sunil and Rachita Gulati, "Did efficiency of Indian public sector banks converge with banking reforms?," International Review of Economics, March 2009, 56 (1), 47-84.

Kumbhakar, Subal C and Subrata Sarkar, "Deregulation, Ownership, and Productivity Growth in the Banking Industry: Evidence from India," Journal of Money, Credit and Banking, June 2003, 35 (3), 403-424.

Sanyal, Paroma and Rashmi Shankar, "Ownership, Competition and Bank Productivity: An Analysis of Indian Banking in the Post-Reform Period," International Review of Economics and Finance, 2011, 20, 225247.

Sathye, Milind, "Efficiency of banks in a developing economy: The case of India," European Journal of Operational Research, 2003, 148, 662-671. 
Sengupta, Rajeswari and Harsh Vardhan, "Non-performing Assets in Indian Banks : This Time It Is Different," Economic and Political Weekly, 2017, 52 (12).

Sensarma, Rudra, "Are foreign banks always the best? Comparison of state-owned, private and foreign banks in India," Economic Modelling, July 2006, 23 (4), 717-735. 


\section{$5 \quad$ Figures and tables}

Figure 1: Total number of employees in the Indian banking system, 19922018

Note: This figure shows the total number of employees in private sector banks, public sector banks and all other commercial banks in India.

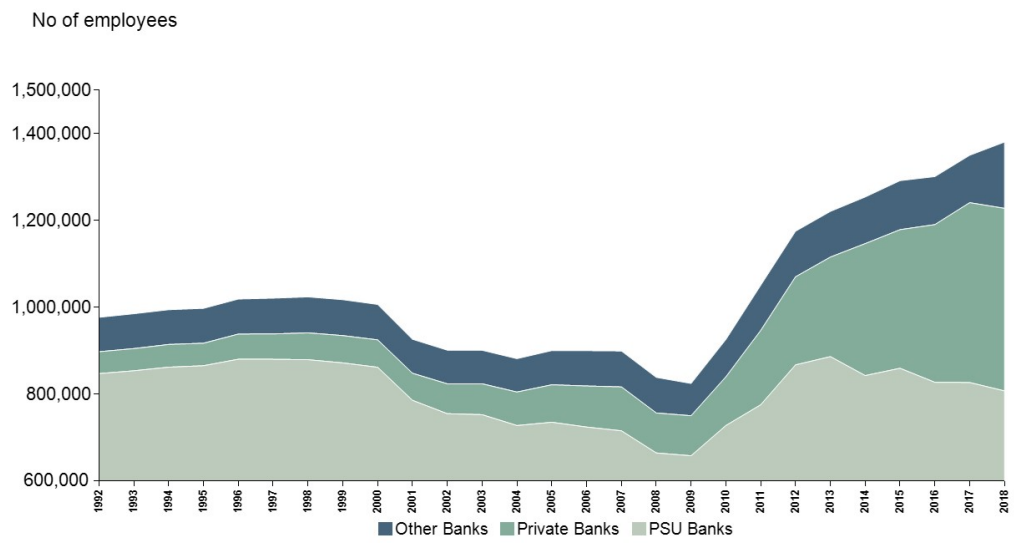

Figure 2: Total balance sheet of the Indian banking system, 1992-2018

Note: This figure shows the total balance sheet size of the private sector banks, public sector banks and all other commercial banks in India.

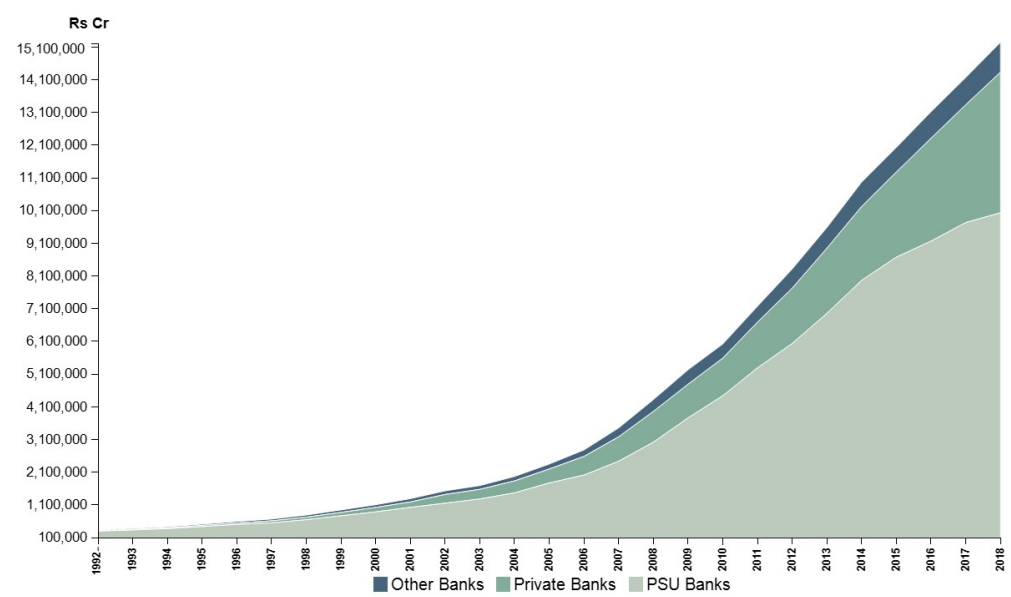


Figure 3: Cost of intermediation of the Indian banking system, 1992-2019 Note: This figure shows the evolution over time of two measures of productivity in Indian banking: ratio of operating costs to total income and ratio of operating costs to average total assets of all commercial banks.

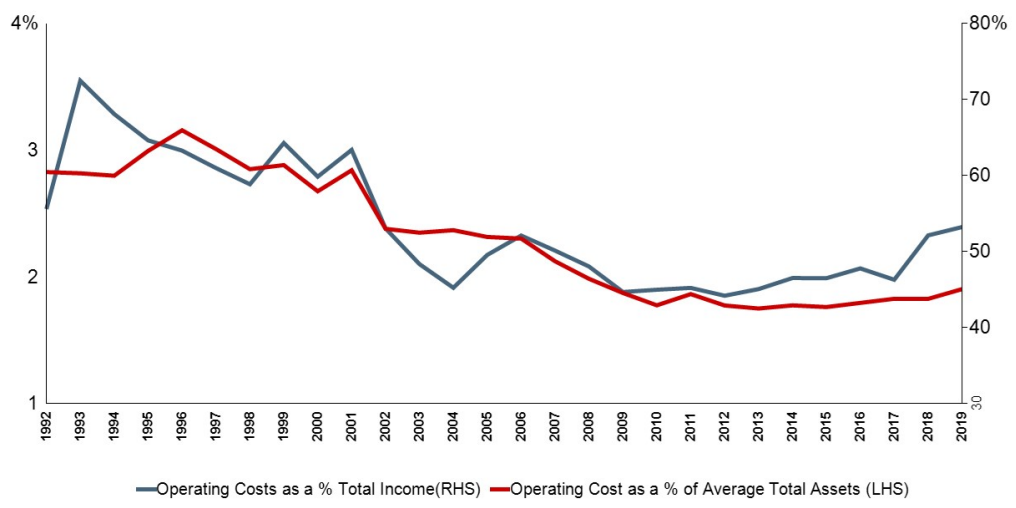

Figure 4: Cost of intermediation for various groups of banks, 1992-2019 Note: This figure shows the evolution over time and across groups of banks of the ratio of operating costs to average total assets. The four bank groups are private sector banks which include the old and the new private banks, foreign banks, State Bank of India and its associates and the non-SBI public sector banks.

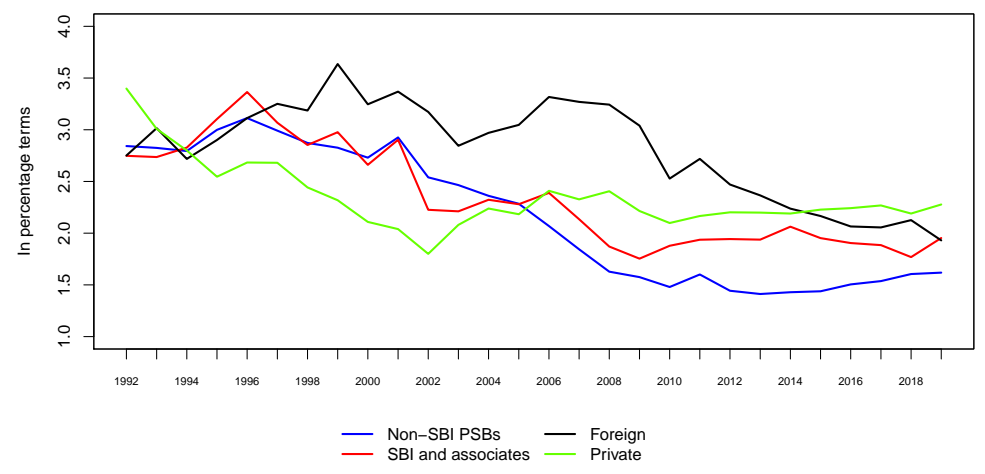


Figure 5: Term Deposit Pricing Relative to Risk Free Government Security Yield

Note: This figure shows the annual average interest rate on term deposits of all banks and the yield of 5-year G-Secs for the period 1997 to 2019. Interest on term deposits is calculated as the difference between total interest on deposits and interest on savings account (calculated at about $3.8 \%$ on average deposits). Interest rate of term deposits is obtained as the ratio of interest on term deposits and average term deposits between two years.

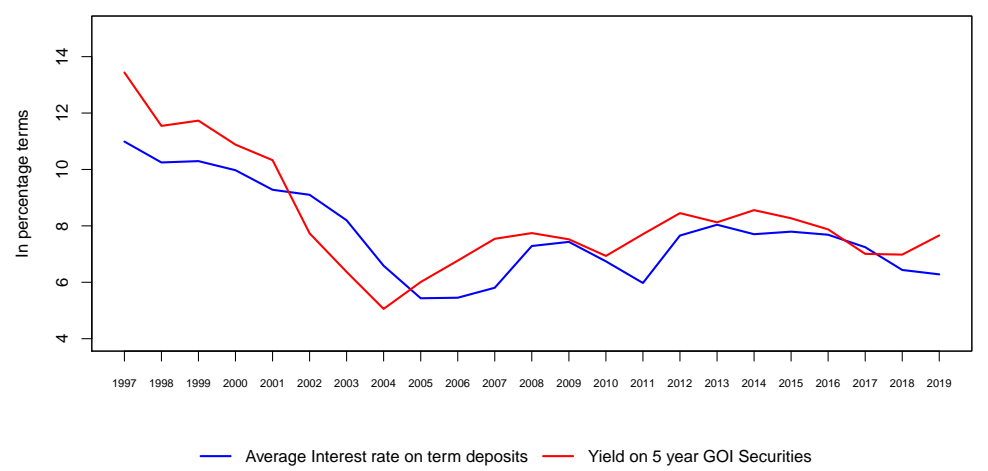

Figure 6: Term Deposit Pricing Relative to Risk Free Government Security Yield across Bank Groups

Note: This figure shows the annual average interest rate on term deposits of the four groups of banks and the yield of 5-year G-Secs for the period 1997 to 2019. Interest rate of term deposits is obtained in the same way as in figure 5 and the four groups of banksare the same as in figure 团

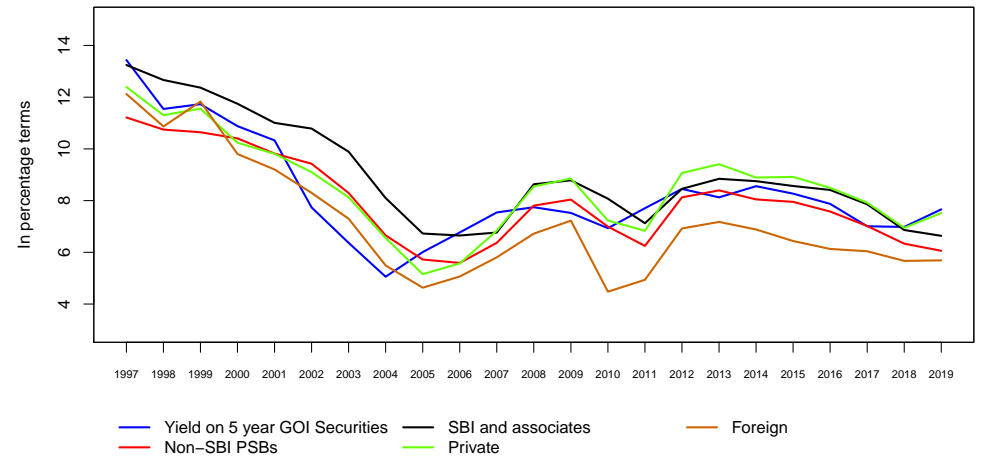


Figure 7: Average Loan Pricing relative to Risk Free Government Security Yield

Note: This figure shows the annual average yield on loans for all commercial banks and the 10 year government security yield. Average yield on loans is calculated as the ratio between interest earned on loans and average total loans and advances across two consecutive years.

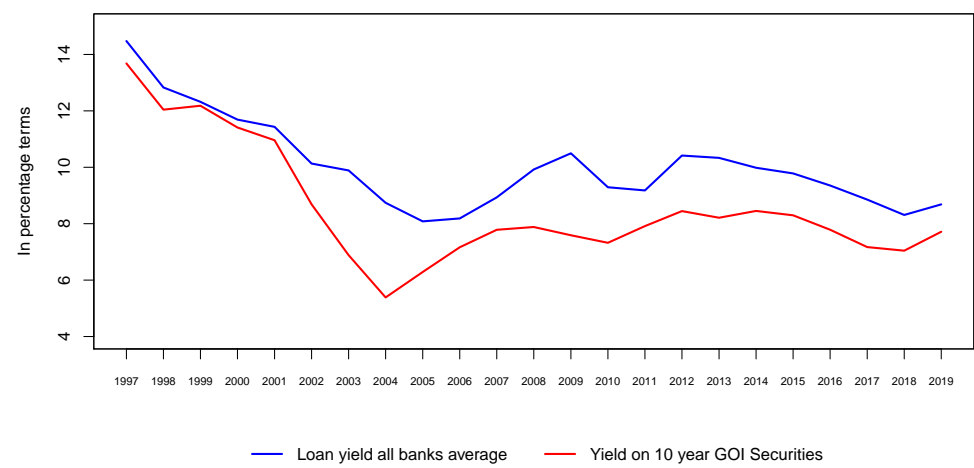

Figure 8: Average Loan Pricing relative to Risk Free Government Security Yield across bank groups

Note: This figure shows the annual average yield on loans for the four groups of banks and the 10 year government security yield. Average yield on loans is calculated as the ratio between interest earned on loans and average total loans and advances across two consecutive years. The four bank groups are the same as in figure 4.

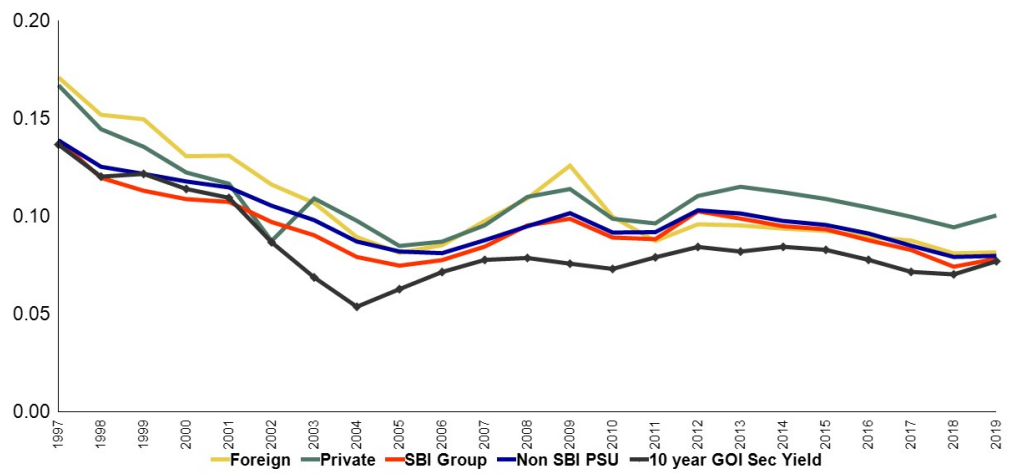


Figure 9: Employee Costs as a Percentage of Total Assets and Income Note: This figure shows the evolution over time of the share of employee wages and salaries in total income as well as in average total assets of all commercial banks.

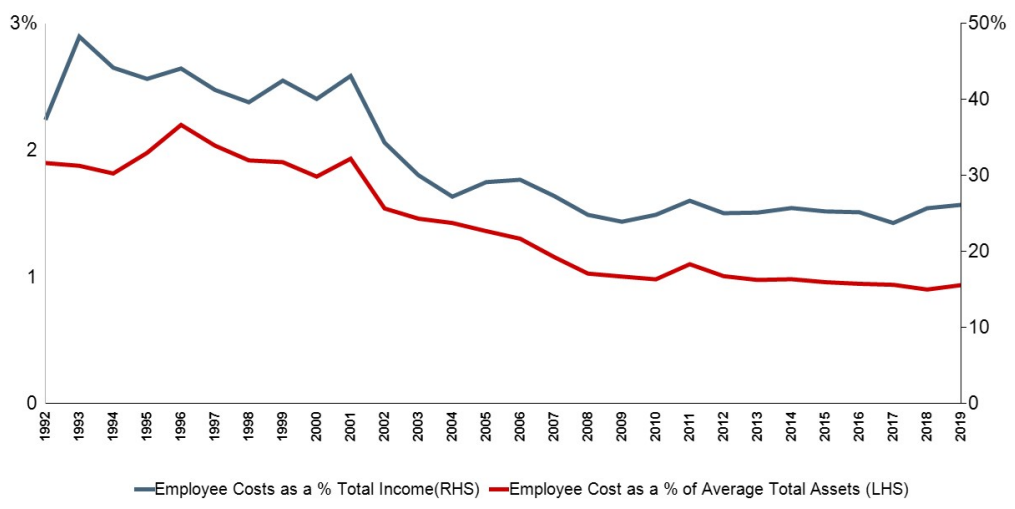

Figure 10: Real Per Employee Compensation and Total Balance Sheet of the Banking System

Note: This figure shows the evolution over time of the total wages and salaries of employees of all commercial banks and the total annual assets of the banks, both parameters deflated by the consumer price index of the respective years.

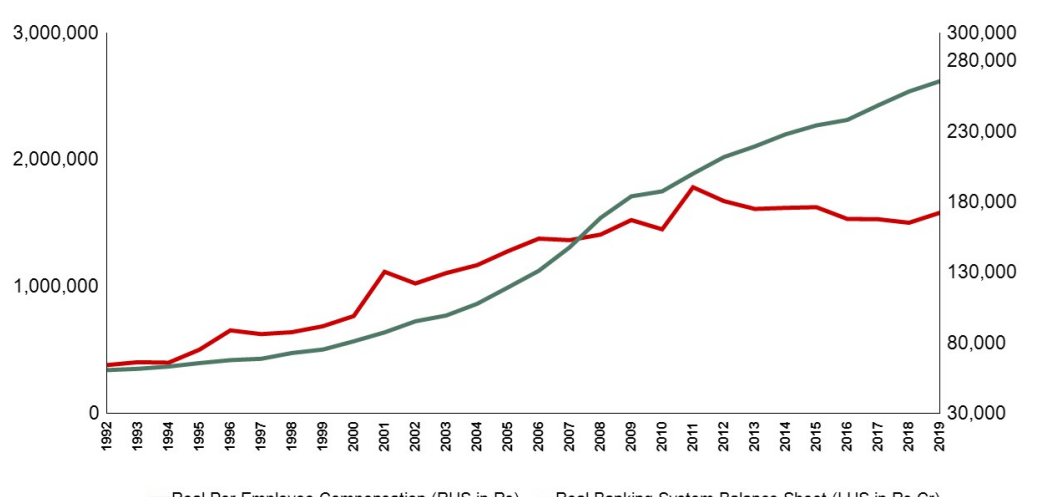


Figure 11: Real Per Employee Compensation and Total Balance Sheet of the private sector banks

Note: This figure shows the evolution over time of the total wages and salaries of employees of the private sector banks and the total annual assets of the banks, both parameters deflated by the consumer price index of the respective years.

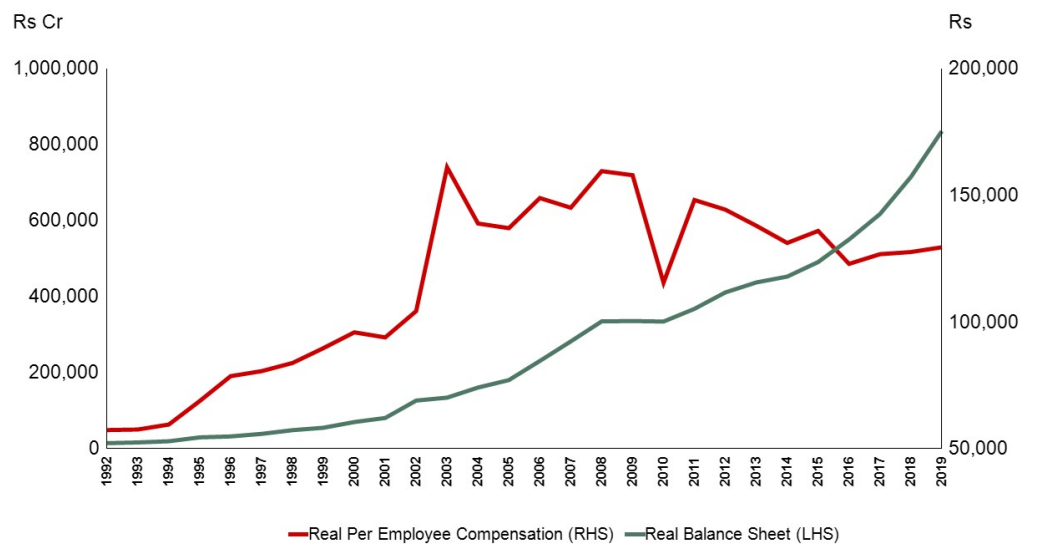

Figure 12: Real Per Employee Compensation and Total Balance Sheet of the public sector banks

Note: This figure shows the evolution over time of the total wages and salaries of employees of the public sector banks and the total annual assets of the banks, both parameters deflated by the consumer price index of the respective years.

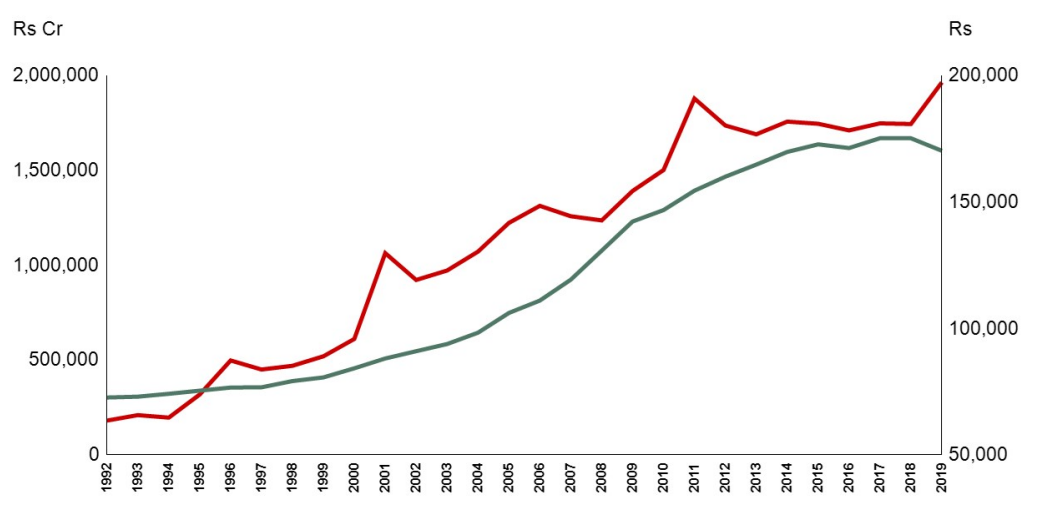


Figure 13: Operating cost and Operating Profits of Indian Banking, 19922019

Note: This figure shows the ratio of operating costs to average total assets and the ratio of pre provisioning operating profits to average total assets of all commercial banks.

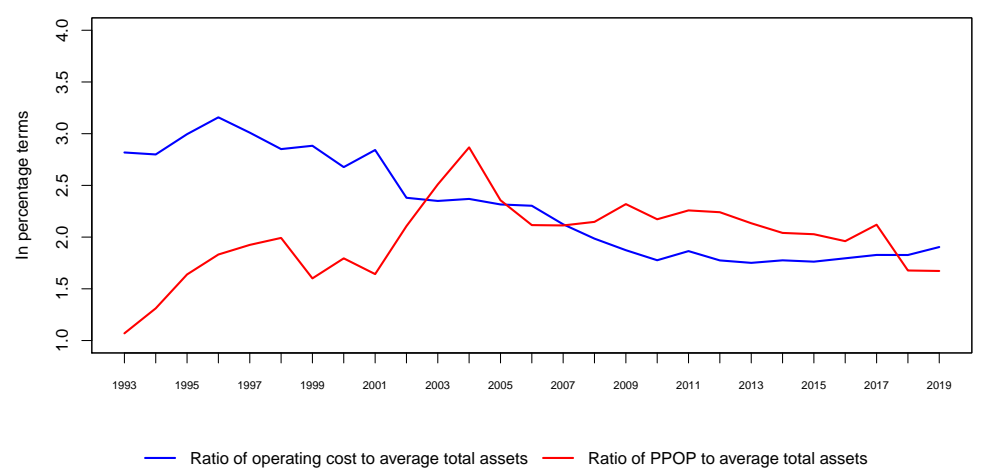

Figure 14: Cost of Intermediation, Pre-provisioning Operating Profits and Gross NPAs of PSBs, 1997 - 2018

Note: This figure shows the evolution over time of the total wages and salaries of employees of the private sector banks and the total annual assets of the banks, both parameters deflated by the consumer price index of the respective years.

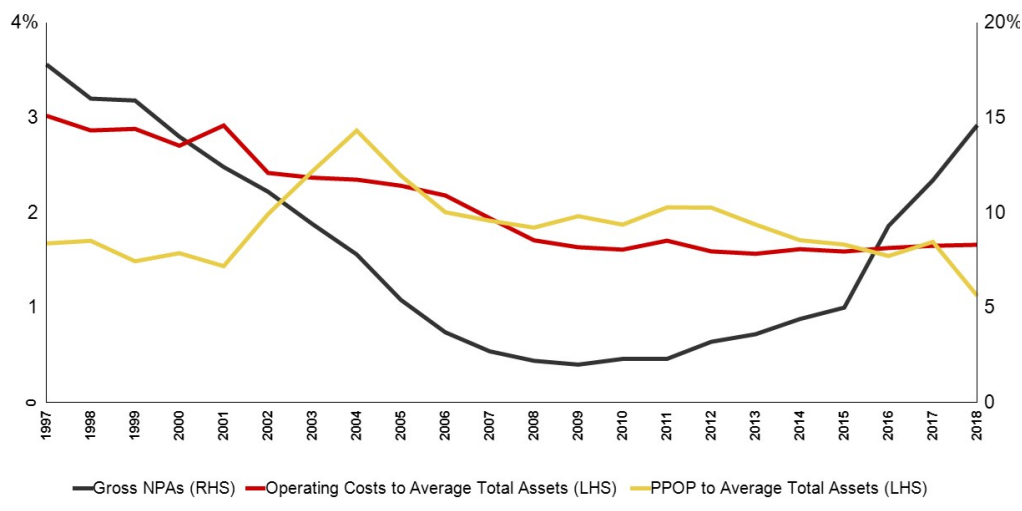


Figure 15: Cost of Intermediation, Pre-provisioning Operating Profits and Gross NPAs of Private banks, 1997 - 2018

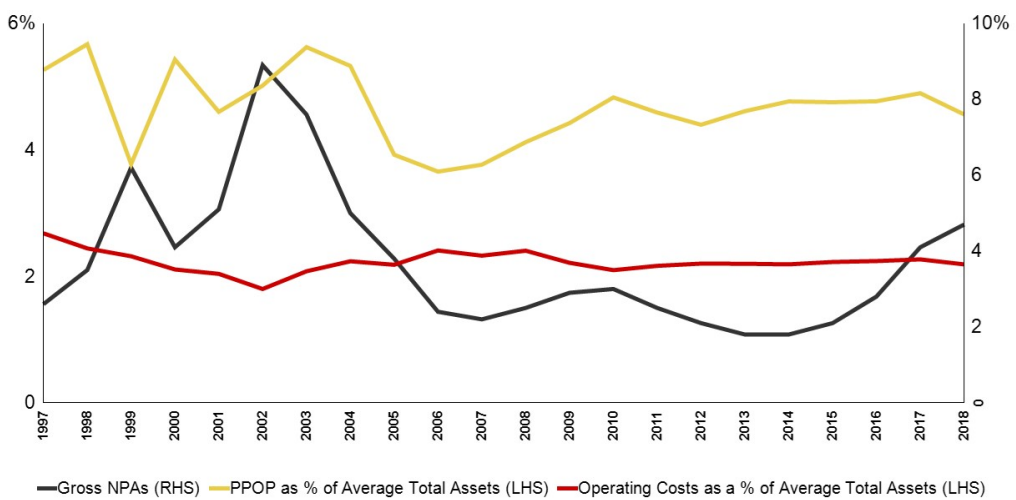

